\title{
Nowoczesne trendy w produkcji lutowanych wymienników ciepła dla przemysłu motoryzacyjnego
}

\author{
Modern trends in production \\ of brazed heat exchangers \\ for automotive industry
}

\section{Streszczenie}

W artykule przedstawiono najnowsze kierunki w zakresie produkcji aluminiowych wymienników ciepła stosowanych w przemyśle motoryzacyjnym. Zaprezentowano zmiany dotyczące zaostrzenia wymagań stawianych aktualnie produkowanym wymiennikom ciepła. Podano wpływ czynników na konstrukcję wymiennika ciepła oraz na technologię lutowania twardego, najczęściej stosowaną w ich produkcji.

Słowa kluczowe: stopy aluminium AA1050; AA3003; AA4343; AA6060; aluminiowy wymiennik ciepła; lutowanie twarde

\begin{abstract}
The article has presented the latest trends in the production of aluminum heat exchangers used in the automotive industry. Presented changes mainly pertain to tightening requirements for currently manufactured heat exchangers. The effect of factors on the heat exchanger design and brazing technology which is commonly used in their production has been given.
\end{abstract}

Keywords: aluminum alloys AA1050; AA3003; AA4343; AA6060; aluminum heat exchanger; brazing

\section{Wstęp}

Początek stosowania wymienników ciepła w przemyśle motoryzacyjnym sięga końca XIX wieku, kiedy Wilhelm Maybach opatentował chłodnicę rurkową, stanowiącą wymiennik cieczy chłodzącej silnik (radiator). Od tego czasu wymienniki ciepła stosowane w przemyśle samochodowym rozpoczęły swój proces ewolucji, zarówno jeśli chodzi o używane przy ich produkcji materiały jak i technologie spajania. Dodatkowo wraz postępem technologicznym (dostępnością coraz bardziej nowocześniejszych urządzeń do ich wytwarzania) nastąpił rozwój wymienników ciepła poprzez zmianę konstrukcji samych rurek, płytek oraz taśm rozpraszających ciepło, wraz z tym nastąpiło usprawnienie samych procesów spajania. Stopniowo pojawiały się też nowe obszary, w których zastosowano wymienniki ciepła, grzejnik układu klimatyzacji (heater core), skraplacz układu klimatyzacji (condenser), parownik układu klimatyzacji (evaporator), chłodnica oleju skrzyni biegów (transmission oil cooler), chłodnica oleju silnika (engine oil cooler) chłodnia powietrza doładowanego (charge air cooler), chłodnice paliwa (fuel cooler).

\section{Wymienniki ciepła oparte na miedzi i jej stopach lutowane na miękko}

Początkowo powszechnie stosowano wymienniki z miedzi i jej stopów (głównie mosiądzu) lutowane na miękko, głównie z zastosowaniem lutów na osnowie $\mathrm{Sn}-\mathrm{Pb}$. Wymienniki wytwarzane tą technologią mimo doskonałych parametrów przewodnictwa cieplnego były droższe w wytwarzaniu oraz miały większą masę w stosunku do obecnie używanych wymienników ciepła opartych na stopach aluminium. Aktualnie technologia ta jest rzadko stosowana (głównie w produkcji jednostkowej i małoseryjnej), szczególnie tam gdzie występują duże wymagania odnośnie wydajności lub odporności wymiennika na trudne warunki pracy. Takie warunki mogą być spowodowane występowaniem: zwiększonych wibracji, szoków termicznych oraz gwałtownych zmian ciśnienia cieczy lub gazu w określonym obiegu wymiennika. Wymienniki z miedzi i jej stopów charakteryzują się długą żywotnością. Warto podkreślić, że wymienniki tego rodzaju są nadal dość powszechnie produkowane w krajach mniej rozwiniętych, w wyniku transferu maszyn i technologii z krajów

Prof. dr hab. inż. Zbigniew Mirski - Politechnika Wrocławska; mgr inż. Jarosław Pabian - MAHLE Behr Ostrów Wielkopolski Park Technologiczny.

Autor korespondencyjny/Corresponding author. zbigniew.mirski@pwr.edu.pl 


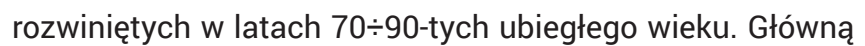
zaletą stosowania technologii "miedziano-mosiężnej” jest szerokie "okno lutowania", tj. szeroki zakres temperatury lutowania. Temperatura topnienia stosowanych mosiądzów wynosi $915 \div 955^{\circ} \mathrm{C}$, a w przypadku miedzi $1050 \div 1080{ }^{\circ} \mathrm{C}$, przy temperaturze topnienia lutu dochodzącej do $400{ }^{\circ} \mathrm{C}$. W tej technologii, przed procesem spajania na elementy nanoszono topniki, w których dominowały tak agresywne składniki jak kwas solny i chlorek cynku, grożące powstaniem korozji przy braku usunięcia żużla potopnikowego.

\section{Wymienniki oparte na stopach aluminium wykonywanych w technologii rurek rozpęczanych}

Kolejnym etapem rozwoju były wymienniki wytwarzane w technologii rurek rozpęczanych (nazywaną w branży potocznie technologią Tube\&Fin) - oparte na wykorzystaniu stopów aluminium, gdzie poszczególne elementy nie były łączone poprzez procesy spajania. Wymiennik wykonywany w technologii T\&F składał się z rurek o przekroju okrągłym lub owalnym (grubość ścianek w zakresie 0,35 do 0,4 mm, przykładowy materiał AA3103), przez które przepływał czynnik chłodzący, a ciepło było rozpraszanie przez taśmy płaskie lub przeformowane o grubości ok. 0,1 mm z otworami (przykładowy stop AA1050A), na które były „nawlekane rurki". Na końcach rurek były zakładane grubsze płyty - płyty sitowe, które wraz z uszczelką "gumową" były łączone z rurkami przez ich przeformowanie (rozpęczanie). Finalnie do grubszych płytek były zaciskane zbiorniki wykonane z tworzywa sztucznego. Technologia ta nie wymagała spajania, jednakże wymienniki te miały ograniczenia jeśli chodzi o ich wielkość. Miały one zdecydowanie mniejszą masę oraz cenę przy podobnych gabarytach w porównaniu z poprzednią technologią. Obecnie, podobnie jak w przypadku technologii "miedziano-mosiężnej”, technologia T\&F jest stosowana w produkcji małoseryjnej.

Zestawienie właściwości materiałów stosowanych na wymienniki ciepła zamieszczono w tablicy I.

\section{Wymienniki ciepła oparte na stopach aluminium wykonywane $\mathrm{w}$ procesie lutowania twardego}

Obecnie większość stosowanych wymienników ciepła w przemyśle motoryzacyjnym jest wytwarzane technologią lutowania twardego stopów aluminium. Jej początki sięgają lat 70-tych ubiegłego wieku, gdy względy ekonomiczne (koszty wytwarzania i eksploatacji) decydowały o rodzaju stosowanych ówcześnie materiałów i technologii w przemyśle samochodowym. W tej technologii zarówno luty jak i materiały spajane są stopami aluminium, a obniżenie temperatury topnienia lutu w odniesieniu do materiału spajanego uzyskano poprzez dodatek krzemu do aluminium, otrzymując luty siluminowe Al-Si [1]. Materiał używany do produkcji aluminiowych wymienników ciepła ma najczęściej postać folii, taśm lub blach uzyskiwanych w procesie walcowania. Mogą być one dodatkowo platerowane warstwą lutu lub stopami podnoszącymi wytrzymałość mechaniczną czy odporność korozyjną wymiennika. Obecnie w przemyśle motoryzacyjnym najczęściej stosowany jest lut o składzie podeutektycznym AISi7,5, natomiast są jeszcze stosowane luty AISi10 oraz AISi12 (skład bliski eutektycznemu), głównie w miejscach, gdzie temperatura wymiennika podczas lutowania jest lokalnie obniżona. W masowej produkcji aluminiowych wymienników ciepła wykorzystywane są głównie piece tunelowe w oparciu o technologię CAB (Controlled Atmosphere Brazing), czyli lutowanie w atmosferze kontrolowanej (w przypadku lutowania stopów aluminium najczęściej stosowanym gazem obojętnym jest azot) oraz z użyciem niekorozyjnego topnika $\mathrm{NOCOLOK}^{\circledR}$ (nieorganiczna sól fluorkowa $\mathrm{K}_{1-3} \mathrm{AlF}_{4-6}$ ) [2]. Pozwala to osiągnąć o wiele większą wydajność produkcyjną linii lutowania i lepszą powtarzalność procesu spajania, niż $\mathrm{np}$. w piecu wsadowym. W przypadku stosowania tej technologii kłopotliwy wydawać się może stosunkowo wąski zakres temperatury lutowania w odniesieniu do technologii „miedziano-mosiężnej”. Dla spoiwa AISi1 2 temperatura topnienia wynosi ok. $577^{\circ} \mathrm{C}$, natomiast temperatura topnienia materiału rodzimego jest w przedziale ok. $643 \div 655^{\circ} \mathrm{C}$, więc zalecana temperatura lutowania w zależności od zastosowanego spoiwa jest w zakresie $582 \div 621^{\circ} \mathrm{C}$ (tabl. II). Wybór temperatury lutowania zależy od charakteru procesu lutowania: piecowego czy płomieniowego. Jest to bardzo istotne, gdyż np. górna granica temperatury lutowania dla lutu AA4047, wynosząca $604{ }^{\circ} \mathrm{C}$, dla lutowania piecowego, przy tak małej dynamice nagrzewania doprowadziłaby do prawdopodobnego zniszczenia połączeń lutowanych, w wyniku erozji.

W większości obecnie stosowanych pieców do lutowania twardego wraz odpowiednio ustawionym systemem regulacji temperatury, nie jest problemem uzyskanie stabilnych i powtarzalnych warunków obróbki cieplnej wymienników mimo pozornie wąskiego "okna lutowania”, tj. temperatury lutowania. Parametr ten w pewien sposób wskazuje zakres maksymalnej temperatury, jaką wymiennik powinien uzyskać podczas nagrzewania i lutowania. W przemysłowym zastosowaniu technologii lutowania twardego, aby dokładniej opisać

Tablica I. Zestawienie właściwości wybranych materiałów na wymienniki ciepła Table I. Summary of properties of selected materials for heat exchangers

\begin{tabular}{|c|c|c|c|c|c|c|c|}
\hline $\begin{array}{c}\text { Materiał, } \\
\text { oznaczenie }\end{array}$ & $\begin{array}{c}\text { Gęstość } \\
{\left[\mathbf{k g} / \mathbf{d m}^{3}\right]}\end{array}$ & $\begin{array}{c}\text { Temperatura } \\
\text { topnienia } \\
{\left[{ }^{\circ} \mathrm{C}\right]}\end{array}$ & $\begin{array}{c}\text { Przewodność } \\
\text { cieplna } \\
{[\mathbf{W} / \mathbf{m} \cdot \mathbf{K}]}\end{array}$ & $\begin{array}{c}\text { Współczynnik } \\
\text { rozszerzalności } \\
\text { cieplnej } \\
{\left[\mathbf{1 0}^{-6} \mathbf{K}^{-1}\right]}\end{array}$ & $\begin{array}{c}\text { Ciepło } \\
\text { właściwe } \\
{[\mathbf{J} / \mathbf{k g} \cdot \mathbf{K}]}\end{array}$ & $\begin{array}{c}\text { Moduł } \\
\text { sprężystości } \\
\text { podłużnej } \\
{[\mathrm{GPa}]}\end{array}$ & $\begin{array}{c}\text { Wytrzymałość } \\
\text { na rozciąganie } \\
{[\mathrm{MPa}]}\end{array}$ \\
\hline $\begin{array}{c}\text { Stop miedzi } \\
\text { C14300 }\end{array}$ & 8,95 & $1052-1080$ & 377 & 17 & 386 & 115 & 230 \\
\hline $\begin{array}{c}\text { Mosiądz } \\
\text { C26000 }\end{array}$ & 8,53 & $915-953$ & 120 & 19,9 & 377 & 110 & 435 \\
\hline $\begin{array}{c}\text { Stop } \\
\text { aluminium } \\
\text { AA3003 }\end{array}$ & 2,75 & $643-655$ & 160 & 23,2 & 909 & 70 & 145 \\
\hline
\end{tabular}


Tablica II. Zestawienie najważniejszych parametrów lutów siluminowych używanych w produkcji aluminiowych wymienników ciepła dla przemysłu samochodowego [3]

Table II. Summary of most important parameters of silumin clad alloys common used in production of aluminum heat exchangers for automotive industry [3]

\begin{tabular}{|c|c|c|c|}
\hline Oznaczenie lutu & AA4343 & AA4045 & AA4047 \\
\hline Zawartość nominalna krzemu, \% wag. & 7,5 & 10,0 & 12,0 \\
\hline${\text { Temperatura topnienia, }{ }^{\circ} \mathrm{C}}^{\text {Oalecana temperatura lutowania, }{ }^{\circ} \mathrm{C}}$ & $577 \div 613$ & $577 \div 591$ & $577 \div 582$ \\
\hline Zale $^{\circ}$ & $588 \div 604$ & $582 \div 604$ \\
\hline
\end{tabular}

profil obróbki cieplnej, producenci wymienników w oparciu o ogólne zalecenia i własne doświadczenie, określają zalecane i krytyczne szybkości nagrzewania oraz chłodzenia wymienników, które mogą być różne w zależności od fazy obróbki. Dodatkowo ważnym parametrem jest czas obróbki wymiennika powyżej określonej temperatury (np. $577,585 \mathrm{czy} 595^{\circ} \mathrm{C}$ ) oraz wcześniej wspomniana temperatura maksymalna uzyskiwana przez wymiennik podczas obróbki. W zależności od zastosowanych materiałów czasami konieczne jest kontrolowanie różnych procesów dyfuzyjnych, wówczas ważny jest czas przejścia pomiędzy określonymi temperaturami. Przestrzeganie tych zaleceń jest bardzo ważne, po to aby proces lutowania odbywał się w jak najbardziej optymalnym zakresie określonym przez technologów, w celu uzyskania prawidłowych, trwałych i odpornych połączeń. Technolodzy ustawiając parametry procesu lutowania bazują na wytycznych zdefiniowanych na podstawie otrzymanych wyników badań oraz przyjętych ogólnie zasad. Do głównych wytycznych zalicza się: dopuszczalną porowatość lutowiny, wielkość lica lutowiny dla danego połączenia, odpowiednie/dopuszczalne nadtopienie materiału rodzimego (rdzenia), odpowiednią wielkość i kształt ziaren w mikrostrukturze lutowiny oraz eliminację powstawania procesów erozyjnych podczas lutowania. Nawet przy najbardziej rygorystycznie utrzymywanych parametrach pieca lutowniczego, spajanie stopów aluminium, nie byłoby możliwe bez zastosowania topnika, który głównie jest aplikowany w celu usunięcia warstwy tlenków $\mathrm{Al}_{2} \mathrm{O}_{3}$, znajdującej się na powierzchni łączonych elementów aluminiowych [4]. Temperatura aktywności topnika NOCOLOK ${ }^{\circledR}$ zawiera się w zakresie $565 \div 572{ }^{\circ} \mathrm{C}$, wynika ona $\mathrm{z}$ odpowiedniej kompozycji związków $\mathrm{K}_{1-3} \mathrm{AlF}_{4-6}$ [5]. Drugą ważną funkcją, którą pełni topnik to zapewnienie odpowiedniej zwilżalności powierzchni podczas właściwego lutowania, aby umożliwić płynięcie spoiwa. Ostatnią rolą, którą spełnia topnik jest zabezpieczenie powierzchni przed ponownym utlenieniem podczas lutowania, aż do momentu schłodzenia wymiennika poniżej temperatury solidus zastosowanego spoiwa. Oczywiście powyższe cechy są bardzo zależne od ilości aplikowanego topnika oraz jakości atmosfery kontrolowanej (ilości cząsteczek tlenu oraz poziomu jej wilgotności) w piecu lutowniczym. Na jakość atmosfery kontrolowanej ma wpływ szereg czynników, takich jak: poziom czystości stosowanego gazu obojętnego (im mniejsza zawartość cząstek tlenu tym lepiej), określenie ilości aplikowanego gazu obojętnego do poszczególnych miejsc pieca, właściwe ukierunkowanie rozpływu gazu obojętnego, kondycja systemu kurtyn przeciwdziałających przedostawaniu się tlenu do wnętrza pieca oraz przeciwdziałanie, aby ze wsadem do pieca nie przedostały się pozostałości oleju, wody lub innych niepożądanych substancji, które mogłyby ulec rozkładowi w wyniku oddziaływania temperatury panującej w piecu.

\section{Materiały jedno- i wielowarstwowe w budowie wymienników ciepła}

W ostatnim czasie w wyniku współpracy producentów wymienników ciepła oraz dostawców stopów aluminium (z których produkowane są wymienniki), rozwinięto szereg nowych materiałów używanych w produkcji wymienników. Dotyczy to zarówno składu chemicznego stosowanych stopów oraz ilości warstw z którego składa się blacha, taśma czy folia używana w procesie produkcji. Obecnie stosowane są materiały, których ilość warstw waha się od 1 aż do 5, w zależności od funkcji, jaką pełni dany element wymiennika. Materiały jednowarstwowe są używane do wytwarzania m.in. taśm rozpraszających ciepło lub rur, z których wykonywane są kolektory skraplaczy, w takim przypadku lut znajduje się na częściach z którymi elementy te się łączą. Z punktu widzenia technologii wytwarzania jest to najtańszy produkt, z uwagi na potrzebę kontrolowania tylko grubości takiej walcówki. Materiały dwu- i trzy warstwowe, składają się z warstwy rdzeniowej odpowiednio jednostronnie lub dwustronnie platerowanej lutem (clad alloy) lub stopem separacyjnym (interliner alloy - którego funkcja zostanie wyjaśniona w kolejnym przykładzie) w zależności od zastosowania. Służą one zarówno do produkcji takich elementów wymiennika jak: płyty sitowe, rurki czynnika, wsporniki, separatory kolektorów czy usztywnień (obejm). Grubość jednej warstwy spoiwa z reguły waha się od 5 do $15 \%$ grubości walcówki. W przypadku produkcji tych materiałów koszt wytwarzania, jest wyższy z uwagi na trudniejszy proces technologiczny formowania folii i blach (konieczność odpowiedniego przygotowania pakietu wlewków oraz kontrolowania grubości każdej z warstw w procesie produkcyjnym). Stosowane są też materiały 4i 5-warstwowe, które są rozwinięciem materiału 3-warstwowego, po aby zwiększyć odporność mechaniczną lub/oraz odporność korozyjną. Ważną rolę spełnia tutaj warstwa separacyjna, która w jednym przypadku (w zależności od użytego stopu) stanowi ochronę korozyjną warstwy rdzeniowej przed czynnikami środowiskowymi lub zewnętrznymi (przykładem może być zmodyfikowany stop AA3003) [6]. W innym przypadku warstwa ta może stanowić barierę przed dyfuzją cząstek magnezu z materiału rdzeniowego do materiału lutu, zapewniając większe właściwości mechaniczne przy zachowaniu dobrej lutowności (przykładem może być zmodyfikowany stop AA1050). Nie jest to jednak takie oczywiste w przypadku stosowania materiałów 3-warstwowych, w których w stopie rdzeniowym jest podwyższona zawartość $\mathrm{Mg}$ - co zostanie opisane w dalszej części artykułu. Na rysunku 1 przedstawiono przykładowe schematy budowy materiałów wielowarstwowych, a na rysunku 2 ich przekroje poprzeczne. W tablicy III zamieszczono skład chemiczny przykładowych stopów separacyjnych. Analogicznie jak wspomniano wcześniej, walcówki składające się z 4 czy 5 warstw są najtrudniejsze do wykonania w procesie technologicznym, co się również przekłada na cenę, ale niejednokrotnie są jedynym rozwiązaniem zapewnienia określonych wymagań stawianym wymiennikom ciepła. Każdy z producentów stopów aluminium ma w ofercie różne pakiety materiałów wielowarstwowych, różniących się zarówno składem chemicznym, grubością poszczególnych warstw oraz procesem obróbki plastycznej. 
a)

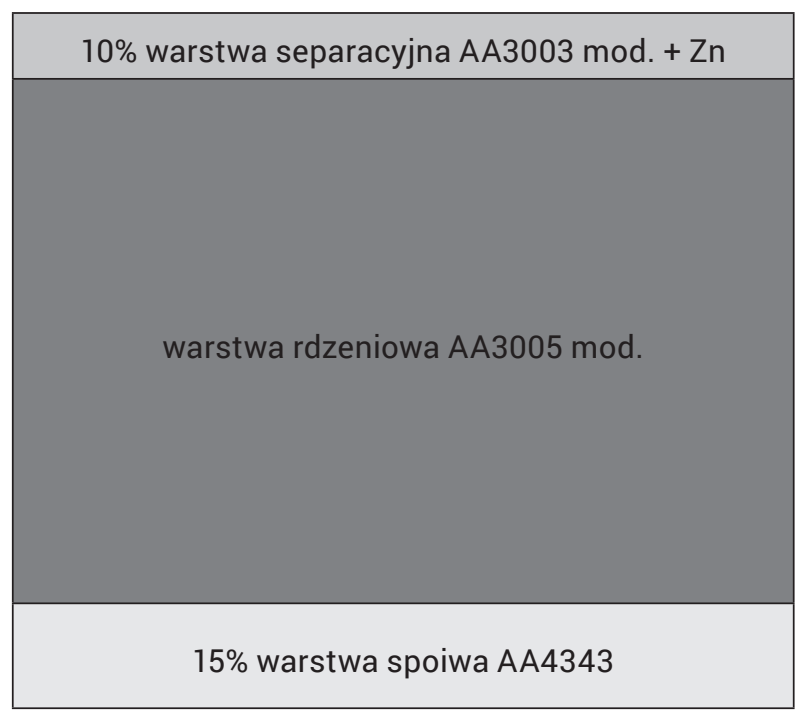

c)

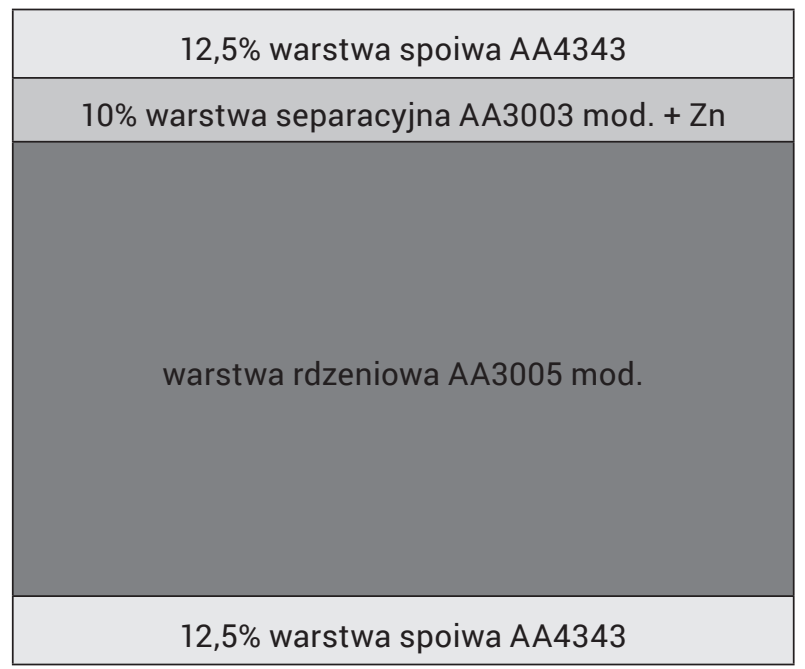

b)

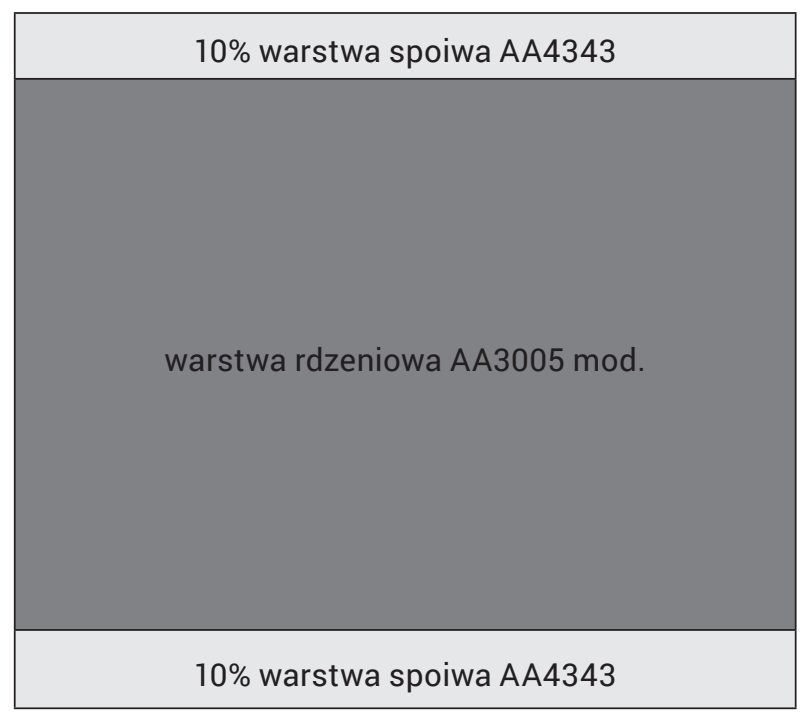

d)

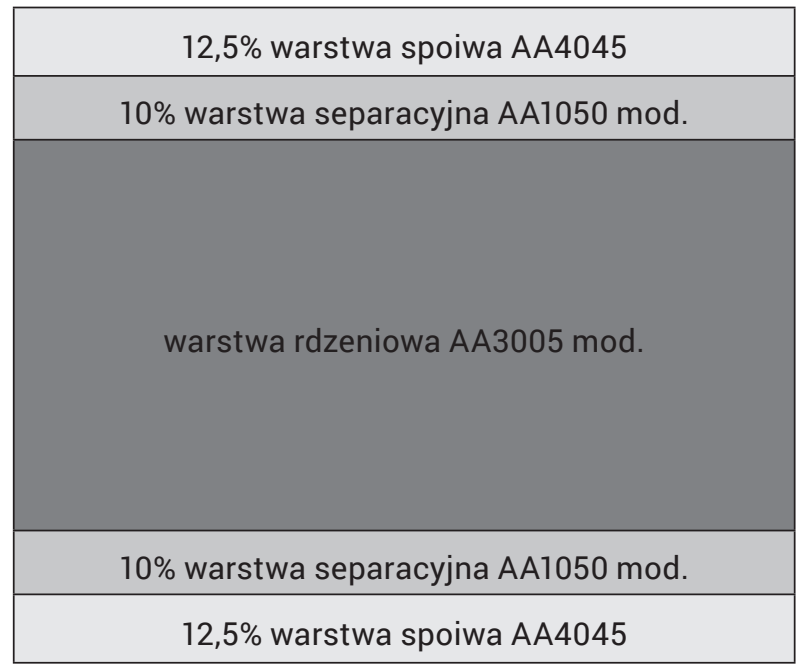

Rys. 1. Przykładowe struktury materiałów wielowarstwowych: 3-warstwowa ze stopem separacyjnym (a), 3-warstwowa (b), 4-warstwowa (c), 5-warstwowa (d)

Fig. 1. Example structures of multilayer sheets: 3-layer with interliner (a), 3-layer (b), 4-layer (c), 5-layer (d)

Tablica III. Skład chemiczny przykładowych separacyjnych stopów aluminium używanych w materiałach wielowarstwowych Table III. Chemical composition of example aluminum interliner alloys used in multilayers materials

\begin{tabular}{|c|c|c|c|c|c|c|c|c|c|c|c|}
\hline \multirow{2}{*}{$\begin{array}{c}\text { Oznaczenie } \\
\text { stopu }\end{array}$} & \multicolumn{10}{|c|}{ Skład chemiczny, \% wag. } \\
\cline { 2 - 12 } & Al & Si & Fe & $\mathbf{C u}$ & $\mathbf{M n}$ & $\mathbf{M g}$ & $\mathbf{C r}$ & $\mathbf{N i}$ & $\mathbf{Z n}$ & Ti & Pozostałe \\
\hline $\begin{array}{c}\text { AA1050 } \\
\text { zmodyfikowany }\end{array}$ & reszta & $0,3 \div 0,45$ & do 0,25 & do 0,05 & do 0,05 & do 0,05 & do 0,05 & do 0,05 & do 0,10 & do 0,05 & $\begin{array}{c}\text { każdy do } 0,05 \\
\text { w sumie do } 0,15\end{array}$ \\
\hline $\begin{array}{c}\text { AA } 3003 \\
\text { zmodyfikowany }\end{array}$ & reszta & $0,65 \div 1,1$ & do 0,7 & do 0,05 & $1,3 \div 1,9$ & do 0,05 & - & - & $1,2 \div 1,9$ & do 0,05 & $\begin{array}{c}\text { każdy do } 0,05 \\
\text { w sumie do } 0,15\end{array}$ \\
\hline
\end{tabular}

\section{Rodzaje konstrukcji wymienników ciepła i ich wpływ na lutowanie}

Dotychczas najbardziej rozpowszechnioną i stosowaną konstrukcją aluminiowego wymiennika ciepła w motoryzacji jest równoległe połączenie rurek o przekroju prostokątnym, pomiędzy którymi osadzone są uformowane taśmy (przekrój jest najczęściej w postaci trójkątnego przebiegu okresowego), z dodatkowymi nacięciami, aby zwiększyć wydajność wymiennika. Na końcach rurek montowane są w zależności od przeznaczenia wymiennika, płyty z otworami (płyty sitowe) lub rury o przekroju okrągłym (kolektory). Formowanie płyt sitowych czy też kolektorów odbywa się za pomocą procesu tłoczenia. Pakiet rurek i taśm chłodzących musi zostać skompresowany w czasie montażu wymiennika, tak aby podczas lutowania uzyskać szczeliny pomiędzy elementami zapewniające zjawisko kapilarności. Kompresja wspomnianego pakietu podczas lutowania jest zapewniana poprzez dedykowane oprzyrządowanie (często nazwane ramką lutowniczą) wykonane najczęściej ze stali nierdzewnej, które może dodatkowo pozycjonować lub podpierać w czasie lutowania wybrane elementy wymiennika, aby uniknąć jego deformacji lub uszkodzeń. Obecnie rurki czynnika stosowane wymiennikach najczęściej są produkowane poprzez odpowiednie uformowane taśmy aluminiowej $\mathrm{w}$ procesie walcowania, innym sposobem są rurki otrzymywane $\mathrm{w}$ procesie wyciskania. W zależności 

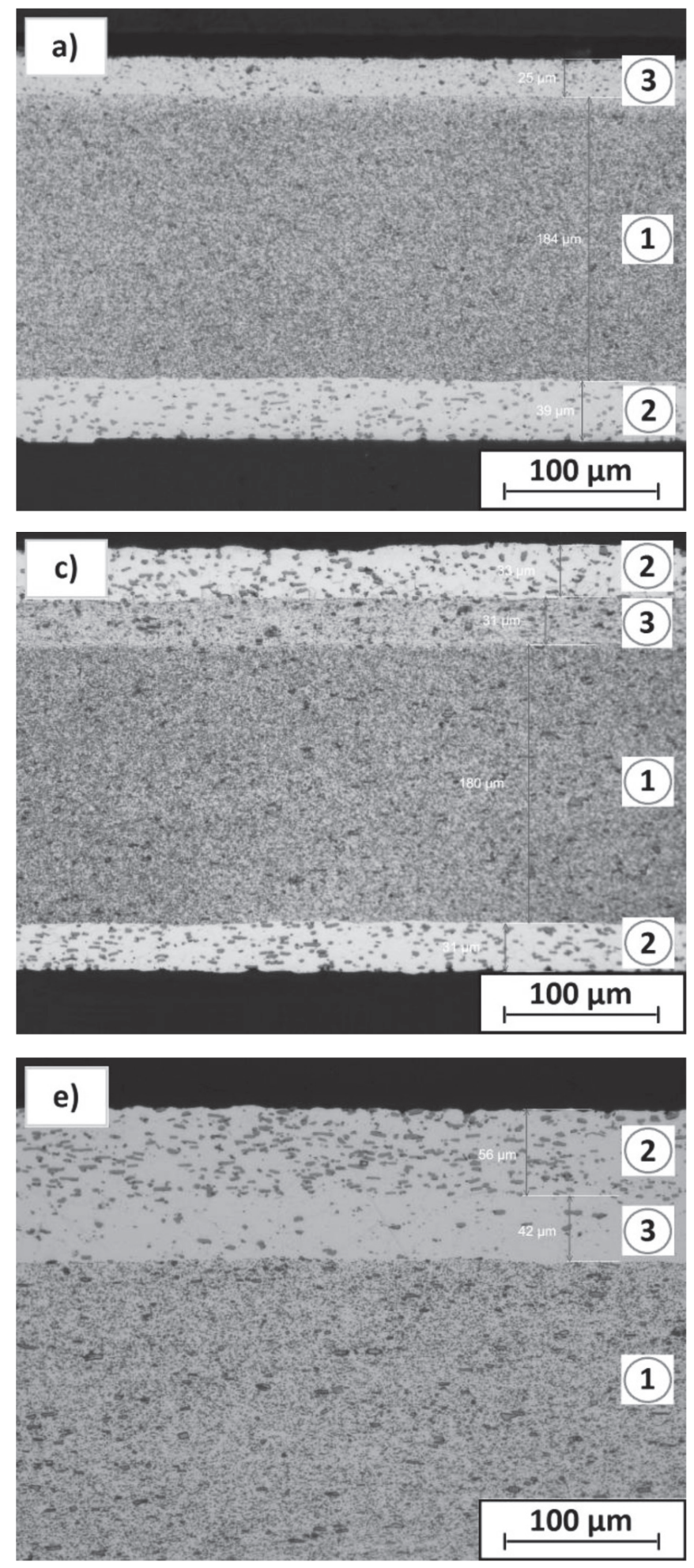

od ciśnienia pracy wymiennika, rurki mają nawet kilka kanałów (wzmocnienie konstrukcji - stosowane dla chłodnic cieczy lub skraplaczy), przez które przepływa czynnik, aby nie doprowadzić do rozerwania rurki podczas eksploatacji. Każdy z wyżej wymienionych procesów ma wpływ na jakość końcową wymiennika uzyskiwaną po procesie lutowania. Większość chłodnic składa się z aluminiowego rdzenia wraz zaciśniętymi do płyt sitowych zbiornikami wykonywanymi z tworzywa sztucznego. Wymienniki tego typu zazwyczaj charakteryzują się z małą lub średnią gęstością, co umożliwia stosowanie względnie krótkich lub średnich cykli lutowania. Długość cyklu lutowania jest zależna w głównym stopniu od konstrukcji wymiennika a ściślej mówiąc jego gęstości (stosunku jego masy do objętości). W większości pieców lutowniczych ciepło do wymiennika
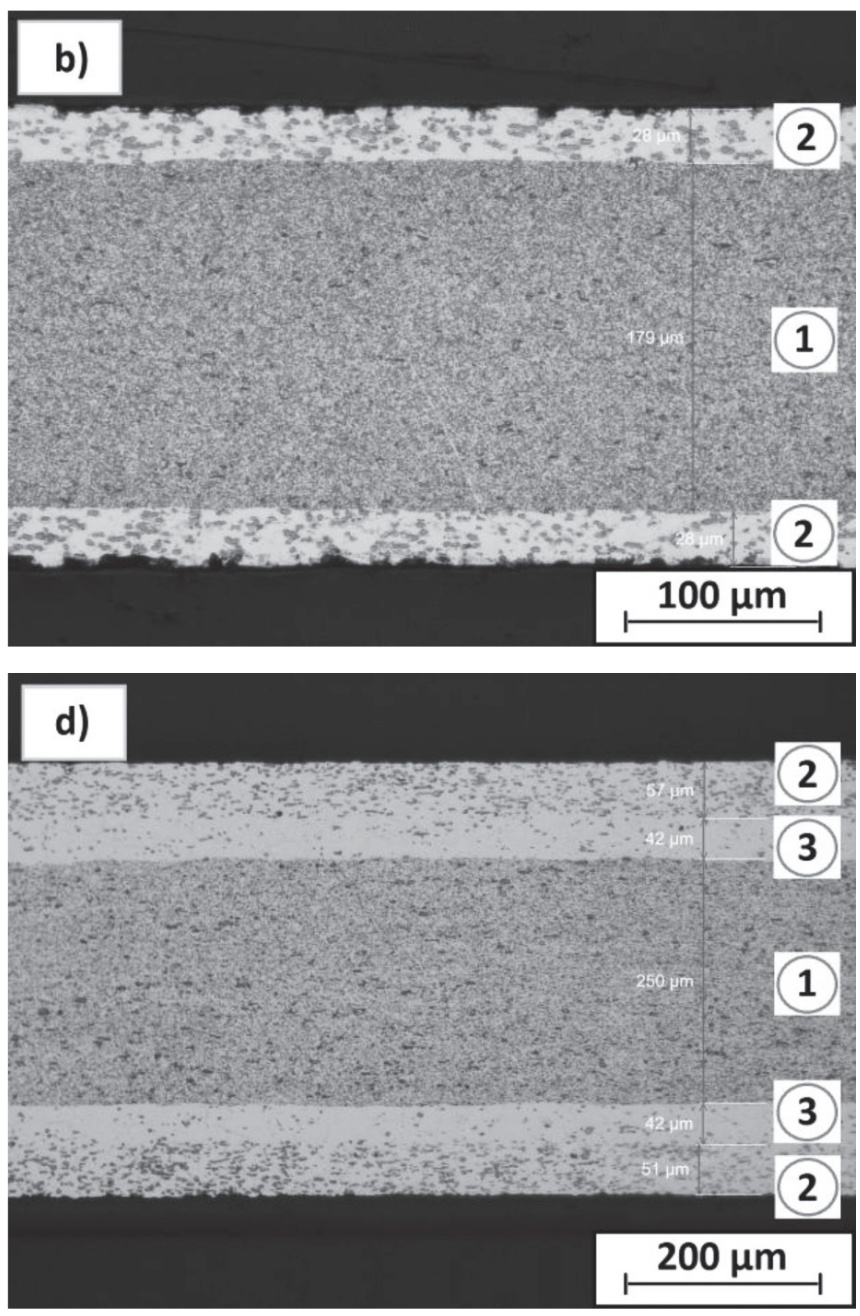

Rys. 2. Przekroje poprzeczne materiałów wielowarstwowych przed procesem lutowania: 3-warstwowy $z$ warstwą separacyjną (a), 3-warstwowy (b), 4-warstwowy (c), 5-warstwowy (d, e), oznaczenie warstw: rdzeń (1), spoiwo (2), separacja (3)

Fig. 2. Cross - sections of multilayer materials before brazing process: 3-layer with interliner (a), 3-layer (b), 4-layer (c), 5-layer (d, e), layers description: core (1), clad (2), interliner (3)

przekazywane jest poprzez radiację (promieniowanie pada na zewnętrzne powierzchnie wymiennika), następnie przedostaje się głębiej poprzez przewodnictwo cieplne. Dla przykładu przy stałej masie wraz ze wzrostem gęstości, maleje powierzchnia całkowita, co powoduje wydłużenie czasu nagrzewania czy studzenia. Inne czynniki, które mają również wpływ na długość cyklu lutowania, to konfiguracja parametrów samej linii lutowania (nastawy temperatury w strefach grzewczych, czy prędkość posuwu transportera) oraz odległości pomiędzy poszczególnymi sekcjami takiej linii, które powodują mniejszą lub większą utratę ciepła przez wymiennik. Na rysunku 3 przedstawiono profile temperaturowe wymienników dla różnych długości cyklu lutowania i zaznaczono temperaturę solidus lutów AISi7,5 - AlSi12, wynoszącą $577^{\circ} \mathrm{C}$. 


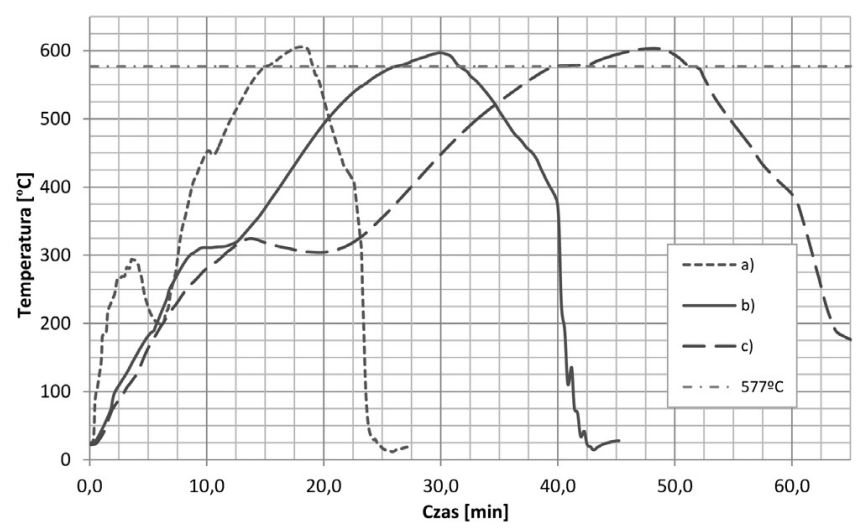

Rys. 3. Porównanie różnych profili temperaturowych wymienników ciepła stosowanych w przemyśle samochodowym: krótki cykl lutowania (a), średni cykl lutowania (b), długi cykl lutowania (c)

Fig. 3. Comparison of different temperature profiles of heat exchangers used in automotive industry: short brazing cycle (a), medium brazing cycle (b), long brazing cycle (c)

Przykładem innej konstrukcji wymiennika są tzw. wymienniki płytkowe, składające się z odpowiednio uformowanych płytek, pomiędzy którymi są umieszone taśmy rozpraszające lub pochłaniające ciepło. Poprzez odpowiednie uformowanie płytek można uzyskać odpowiedni przepływ (prędkość oraz zaburzenie) lub też usztywnienie konstrukcji wymiennika. Tego rodzaju wymienniki są stosowane jako parowniki układów klimatyzacji, chłodnice oleju skrzyni biegów i inne. Konstrukcja tego typu wymienników jest w pełni oparta na elementach wykonanych ze stopów aluminium. Wymienniki tego typu charakteryzują się zwartą budową oraz dużą sztywnością mechaniczną. Ramka lutownicza, która najczęściej jest wykonana ze stali nierdzewnej lub żaroodpornej dla wymienników tego typu, z uwagi na sztywną konstrukcję, wyposażona jest często w dodatkowo elementy sprężyste. Kompensują one różnicę współczynnika rozszerzalności cieplnej stopów aluminium oraz stali, tak aby utrzymać odpowiednią kompresję pakietu i nie zdeformować elementów wymiennika podczas lutowania. Jest to bardzo istotne, gdyż stopy aluminium mają małe własności wytrzymałościowe w temperaturze powyżej $500{ }^{\circ} \mathrm{C}$ [1]. Zazwyczaj wymiary wymienników płytkowych są zbliżone do wymienników opartych na rurkach przy podobnej mocy rozproszenia ciepła. Na rysunku 4 pokazano przykładowe profile temperaturowe dla dwóch rodzajów wymienników: rurkowego oraz płytkowego przy identycznych parametrach technologicznych linii lutowania. Dla wymiennika płytkowego widać wyraźne dłuższe spłaszczenie przebiegu nagrzewania w pobliżu temperatury solidus $577^{\circ} \mathrm{C}$ lutów AISi7,5 - AISi12, wynoszące ok. 3 minut. Taki efekt może być spowodowany zastosowaniem lutu o większej zawartości krzemu lub/i zastosowaniem materiału z większą ilością lutu.

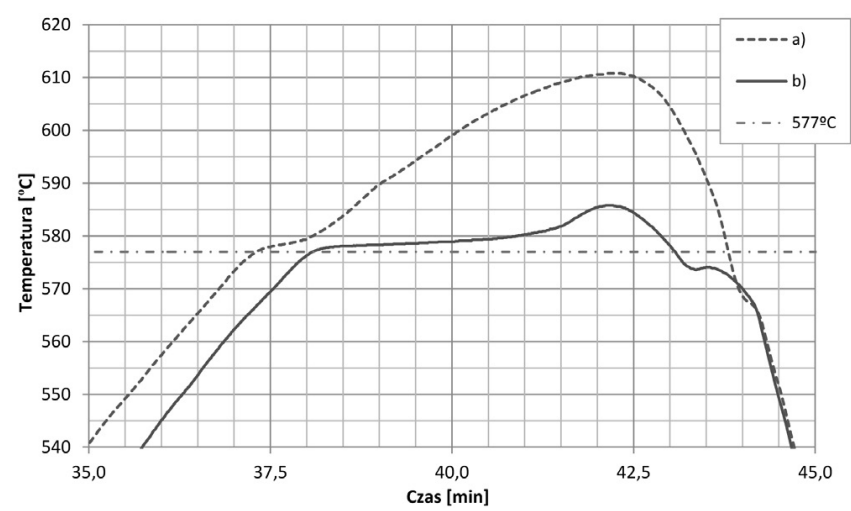

Rys. 4. Porównanie przykładowych profili temperaturowych wymienników rurkowego (a) oraz płytkowego (b)

Fig. 4. Comparison of example temperature profiles of heat exchangers: tube type (a) and plate type (b)

\section{Zwiększone wymagania odnośnie zmniejszenia ilości pozostałości topnika (z uwagi na efekt żelowania cieczy chłodzącej)}

Topnik aplikowany na powierzchnię aluminium, jest niezbędny w procesie lutowania, jednakże po zakończeniu tego procesu wszelkie pozostałości żużla potopnikowego na jego powierzchni pogarszają niektóre właściwości samego wymiennika. W przypadku pozostałości topnika na powierzchni wymiennika, która bierze udział w wymianie ciepła, może nastąpić pogorszenie przewodnictwa cieplnego. Natomiast w zależności od zastosowanych materiałów, środowiska pracy i funkcji wymiennika, miejsce w którym niekorozyjny topnik jest zakumulowany w większej ilości, w szczególnych przypadkach może być źródłem potencjalnych ognisk korozyjnych. Z uwagi na rosnącą liczbę wymienników, która może się znajdować w pętli chłodzenia (szczególnie dotyczy to obiegu niskiej temperatury), pojawił się problem reagowania pozostałości topnika z wnętrza wymiennika z inhibitorem czynnika chłodniczego. Jest to zjawisko, który objawia się wypłukiwaniem pozostałości topnika z wnętrza wymienników znajdujących się w układzie chłodzenia poprzez płyn chłodzący, co może doprowadzić do zdławienia lub nawet zatkania jednego z wymienników z układu - najczęściej chłodnicy niskotemperaturowej z uwagi na najmniejsze pole przekroju i wysokość rurek. Wpływ na powstawanie tej osobliwości ma na pewno: rodzaj czynnika chłodzącego, ilość pozostałego topnika w każdym z wymienników będących w obiegu czynnika chłodzącego, warunki i środowisko, w którym pracują wymienniki ciepła. Co ciekawe zjawisko to nie pojawia się dla wszystkich czynników chłodniczych obecnych na rynku. Pomimo tego producenci samochodów stopniowo zaostrzają normy odnośnie dopuszczalnej ilości pozostałego topnika we wnętrzu wymiennika ciepła. Dlatego zarówno ze względów ekonomicznych jak i tych które mają na celu ograniczenie ww. niedogodności, producenci wymienników nieustannie pracują nad zmniejszeniem ilości aplikowanego topnika, poprzez udoskonalanie istniejących metod oraz rozwijanie nowych selektywnych metod nanoszenia topnika na ściśle określone powierzchnie.

\section{Metody aplikacji topnika oraz innowacyjne materiały beztopnikowe i kompozytowe}

Obecnie jedną z najpopularniejszych metod jest aplikacja topnika w formie natrysku zawiesiny wodnej. W tym przypadku stężenie topnika w zawiesinie waha się od 5 do $25 \%$ wag. i jest zależne od miejsca aplikacji [3]. Topnik tym sposobem z reguły nanoszony na odtłuszczone zewnętrzne powierzchnie wymiennika lub zaburzaczy chłodnic powietrza doładowanego, a po jego nałożeniu części muszą być poddane procesowi suszenia. Innym sposobem to aplikowanie topnika w formie pasty (flux paste) na bazie alkoholi, dzięki czemu można nanosić topnik na nieodtłuszczone powierzchnie wybranych części wymiennika. Stosowany jest głównie na wewnętrzne powierzchnie wymiennika (zwijanych rurek, zaburzaczy, itp,). W tym przypadku w zależności od wymagań, zawartość topnika w mieszaninie może wynosić w zakresie od 5 do $50 \%$ wag. Kolejną metodą to nakładanie topnika w postaci farby (paint flux), poprzez aplikację natryskową na odtłuszczoną powierzchnię 
wybranej części. Wykorzystywana jest do tego mieszanina składająca się topnika od 20 do $45 \%$ wag., środka adhezyjnego od 5 do $10 \%$ wag. oraz reszty, którą jest woda demineralizowana. Podobnie jak dla pierwszego sposobu bezpośrednio po naniesieniu detale muszą być wysuszone, aby związać topnik z powierzchnia elementu. Aplikowanie topnika w postaci farby używane jest dla wybranych części wymiennika jeszcze przed procesem jego montażu. Ta metoda stosowana jest zarówno na zewnętrzne powierzchnie jak płyty sitowe lub kolektory, aby w miejscu ich połączenia z rurkami, polepszyć zwilżalność powierzchni i aktywować większą ilość lutu dla tego typu połączeń. Natomiast aplikacje z użyciem pasty czy farby są używane również dla powierzchni wewnętrznych części wymiennika przed montażem, aby dostarczyć topnik w miejsca gdzie nie dotrze on w przypadku pierwszej metody aplikacji. Stosowana jest jeszcze metoda nakładania topnika w oparciu o zjawiska elektrostatyczne. W tym przypadku naładowane ładunkiem elektrycznym cząstki topnika są natryskiwane $\mathrm{w}$ postaci mieszaniny $\mathrm{z}$ powietrzem na zewnętrzne powierzchnie wymiennika. Zaletą tej metody jest brak konieczności wcześniejszego odtłuszczania. Nie jest ona powszechnie stosowana, gdyż jest chroniona patentem, a jej właścicielem jest jeden $z$ wiodących producentów wymienników ciepła. Ostatnio pojawiły się innowacyjne stopy aluminium, gdzie ziarna topnika są "zatopione" w strukturze lutu w procesie produkcji folii lub taśmy [4]. Materiał ten znany jest pod nazwą Trillium Composite ${ }^{\mathrm{TM}}$, ale na obecną chwilę koszty zakupu i coraz większe trudności w procesie technologicznym wytwarzania tego materiału powodują stosowanie tego rozwiązania głównie w produkcjach małoseryjnych, tam gdzie takie rozwiązanie jest naprawdę konieczne. Natomiast na pewno można stwierdzić, że charakteryzuje się ono bardzo dobrymi właściwościami jeśli chodzi o lutowanie, przy znacznie mniejszym zużyciu topnika, z uwagi na to, że jest on już zawarty w strukturze materiału a warstwa tlenków aluminium jest rozbijana od wewnątrz podobnie jak w lutowaniu próżniowym [7]. Kolejną nową technologią, która wg danych producenta, w odróżnieniu do poprzedniej, nie wymaga użycia topnika w procesie lutowania to CleanBraze ${ }^{\mathrm{TM}}$. Bazuje ona na dotychczasowej technologii wytwarzania folii czy taśmy, z tą różnicą, że w ostatnim kroku produkcyjnym powierzchnia poddawana jest specjalistycznej obróbce (rodzaj obróbki nie jest ujawniony przez producenta), co ma umożliwić lutowanie bez użycia topnika [8]. Również ten materiał, tak jak w przypadku materiału Trillium Composite ${ }^{T M}$, nie jest stosowany na szeroką skalę w przemyśle wielkoseryjnym. Należy podkreślić fakt, że materiały przeznaczone do lutowania bez użycia topnika (flux free) wymagają bardzo dobrej atmosfery podczas lutowania rzędu 20 ppm tlenu i mniej. Lutowanie z użyciem standardowego topnika $\mathrm{NOCOLOK}^{\circledR}$ jest możliwe na poziomie tlenu nie przekraczającym 200 ppm. W przypadku Trillium Composite ${ }^{\mathrm{TM}}$, dobre wyniki lutowania można otrzymać nawet na poziomie 2000 ppm tlenu, co stanowi dużą zaletę dla procesu lutowania [7]. Kolejnym autem kompozytu Trillium Composite $^{T M}$ jest fakt, że podczas lutowania wymiennik cały czas ma srebrny kolor, co w przypadku przekazywania ciepła poprzez radiację w piecu tunelowym, powoduje, że promieniowane nie jest tak silnie odbijane jak w przypadku potopnikowanych wymienników, które do momentu roztopienia się topnika mają biały kolor. Rysunek 5 przedstawia porównanie profili temperaturowych takich wymienników. Powoduje to szybsze nagrzewanie się wymiennika podczas lutowania z uwagi na mniejszy współczynnik odbicia. Obie metody mają ważną wspólną zaletę: brak lub znikomą pozostałość topnika na powierzchni wymiennika po lutowaniu.

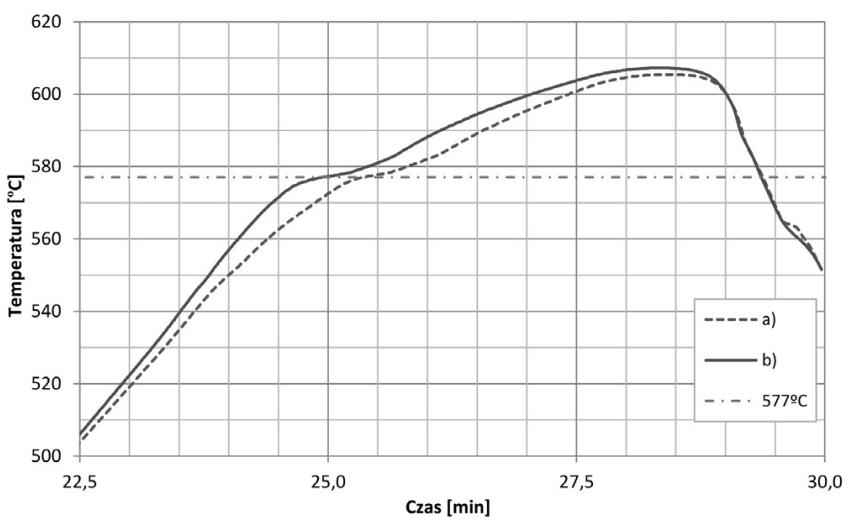

Rys. 5. Porównanie profili temperaturowych przykładowego wymiennika ze standardowego procesu z użyciem topnikowania (a) oraz z użyciem materiału kompozytowego Trillium Composite ${ }^{\mathrm{TM}}$ (b) Fig. 5. Comparison of temperature profiles of example heat exchanger from standard process with fluxing (a) and using a composite material Trillium Composite ${ }^{\mathrm{TM}}$ (b)

\section{Stosowanie stopów ze zwiększoną zawartością magnezu dla zwiększenia wytrzymałości mechanicznej wymiennika i problemy z prawidłowym lutowaniem wymienników}

Z uwagi na rosnące wymagania wytrzymałościowe wymienników, szczególnie jeśli chodzi o odporność na ciągłe zmiany ciśnienia i temperatury, dla polepszenia właściwości mechanicznych wymiennika stosuje się stopy aluminium z dodatkiem Mg. Ten sam zabieg może być stosowany wówczas, gdy przy zachowaniu wymagań wytrzymałościowych wymiennika przy zastosowaniu standardowych stopów, zmniejsza się grubość poszczególnych komponentów, w celu redukcji masy wymiennika. Głównie dotyczy to warstwy rdzeniowej wykonanej ze stopów aluminium serii 3000, używanych do wytwarzania rurek walcowanych i płyt sitowych. Natomiast stopy z większym dodatkiem Mg, takie jak AA6060 czy AA6061 są bardzo powszechnie stosowane do wykonywania bloków przyłączeniowych (block fitting) w skraplaczach. Jednak dodatek magnezu z jednej strony poprawia właściwości mechaniczne z drugiej strony pogarsza właściwości jeśli chodzi o proces lutowania, ponieważ wpływa negatywnie na proces usuwania tlenków przez topnik z powierzchni stopu aluminium. Dzieje się tak dlatego, że magnez dyfunduje do powierzchni materiału podczas lutowania, gdzie łączy się z tlenem, następnie jako tlenek magnezu MgO wchodzi w reakcję z topnikiem tworząc $\mathrm{KMgF}_{3}$, co powoduje zmniejszenie ilości „nieskażonego" topnika, zdolnego usunąć tlenki z powierzchni lutowanego materiału [9]. Intensyfikacja dyfuzji magnezu rozpoczyna się już w temperaturze ok. $425^{\circ} \mathrm{C}$, a więc z reguły jest to jeszcze początkowa część pieca, gdzie może się jeszcze znajdować podwyższona ilość tlenu $w$ atmosferze obojętnej. Przy lutowaniu piecowym zalecana sumaryczna procentowa zawartość magnezu w łączonych ze sobą stopach, przy stosowaniu standardowego topnika $\mathrm{NOCOLOK}^{\circledR}$, nie powinna przekraczać zależności od źródeł od 0,3 do 0,6\% wag. - gdyż ilość aplikowanego topnika w miejsce takiego połączenia ma duże znaczenie na jakość uzyskiwanych połączeń. Bazując na własnym doświadczeniu wspomniana górna granica $0,6 \%$ Mg w stopie $\mathrm{Al}, \mathrm{w}$ masowej produkcji dla lutowania piecowego, prowadzi do słabych i porowatych połączeń lutowanych. Realna i stabilna zawartość Mg to 0,45\% wag. przy lokalnie zwiększonej ilości aplikowanego topnika NOCOLOK ${ }^{\circledR}$ na powierzchnię materiału. 
Dodatkowo negatywny wpływ działania magnezu na proces lutowania można ograniczyć poprzez odpowiednią obróbkę cieplną, a uściślając poprzez szybsze nagrzewanie wymiennika w celu ograniczenia dyfuzji Mg. Natomiast dla lutowania płomieniowego lub indukcyjnego dopuszczalna zawartość Mg w stopie Al jest ograniczona do 1,2\% a nawet wg niektórych źródeł do $2 \%$ wag. Jest to możliwe z uwagi na prędkość nagrzewania lutowanych części, która jest o wiele większa w porównaniu z prędkością nagrzewania dla lutowania piecowego. Zmniejszenie wpływu zależności zawartości magnezu w materiale na stabilność procesu lutowania można jeszcze uzyskać stosując zmodyfikowaną wersję topnika NOCOLOK ${ }^{\circledast}$ z dodatkiem cezu, a dokładnie związku fluoroglinianu cezu - $\mathrm{CsAlF}_{4}$. Zastosowanie dodatku związku cezu, pozwala w pewnym stopniu na neutralizację cząsteczek magnezu, gdzie wskutek ich reakcji otrzymuje się $\mathrm{CsMgF}_{3}$ i/lub $\mathrm{Cs}_{4} \mathrm{Mg}_{3} \mathrm{~F}_{10}$, których temperatura topnienia jest niższa od temperatury topnienia lutu [9]. Zawartość cezu w topniku NOCOLOK ${ }^{\circledR}$ Cs Flux wynosi pomiędzy 1,5 a 2\% wag., gdyż badania wykazały, iż dalsze zwiększenie jego zawartości nie wykazało znacznego polepszenia warunków lutowania, natomiast rośnie wtedy całkowity koszt topnika z uwagi na wysoką cenę cezu na rynku [10]. Zastosowanie tego topnika wg producenta pozwala skutecznie lutować stopy aluminium, w których sumaryczna zawartość magnezu wynosi pomiędzy 0,3 a $0,55 \%$ wag. Na rysunku 6 pokazano mikrostruktury połączeń lutowanych dla różnej zawartości magnezu w warstwie rdzeniowej łączonych materiałów. Pierwsza mikrostruktura (a) przedstawia złącze dwóch materiałów, gdzie sumaryczna zawartość Mg jest mniejsza od 0,2\% wag., lutowina nie jest porowata i można zauważyć nieznaczne rozpuszczenie materiału rdzeniowego rurki. Na drugiej (b) widoczne połączenie materiałów, gdzie zawartość Mg wynosi ok. 0,45\% wag, wykazuje porowatość i braki wypełnienia szczeliny. Brak jest widocznego rozpuszczania materiału rurki, w wyniku szybkiego nagrzewania, dla ograniczenia dyfuzji magnezu.
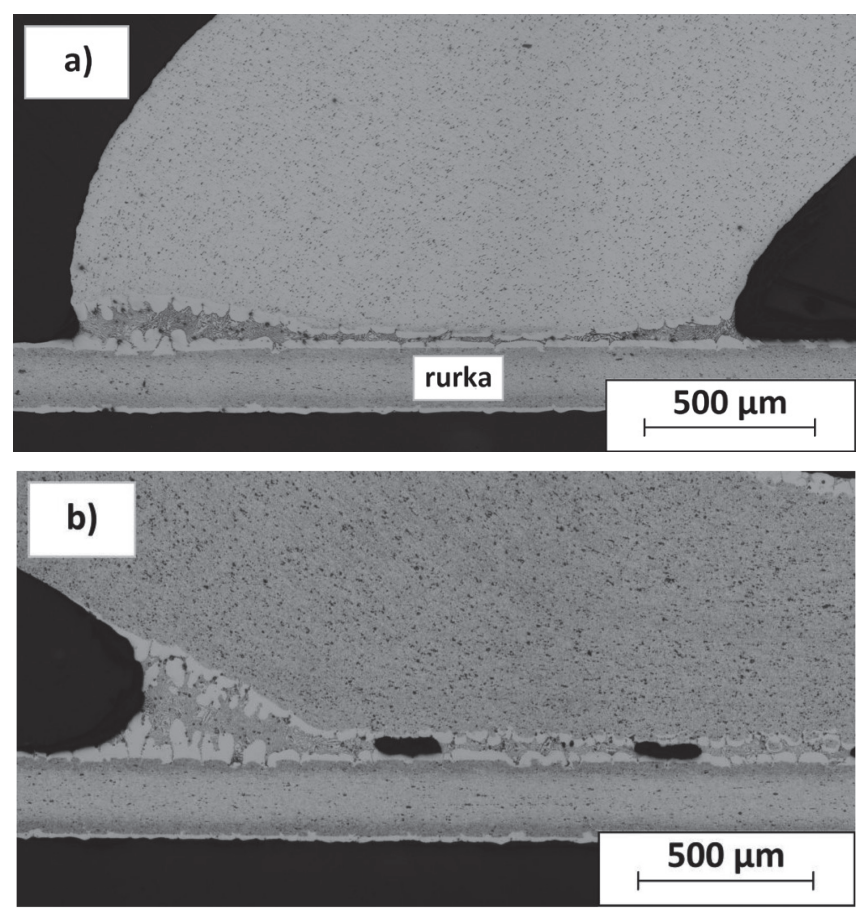

Rys. 6. Mikrostruktura połączeń lutowanych z różną zawartością magnezu w materiale rdzeniowym: sumaryczna zawartość Mg dla obu materiałów rdzeniowych jest poniżej $0,2 \%$ wag. (a), sumaryczna zawartość Mg dla obu materiałów rdzeniowych jest ok. 0,45\% wag. (b)

Fig. 6. Microstructure of brazing joint with different magnesium content in core layer. summary content of $\mathrm{Mg}$ for both core layers is below $0,2 \%$ wt. (a), summary content of $\mathrm{Mg}$ for both core layers is about $0,45 \%$ wt. (b)

\section{Wnioski}

- Mimo wielu zalet materiałów opartych na stopach miedzi, używanych do lutowania wymienników ciepła (szczególnie najnowszej generacji), nadal w dużej większości aktualnie sprzedawanych nowych samochodów są stosowane wymienniki w oparciu o stopy aluminium, gdyż stosunek zarówno ceny i masy dla obu wymienionych materiałów rodzimych jest jak 1:3 na korzyść stopów aluminium,

- Aby poprawić właściwości mechaniczne wymienników ciepła przy jednoczesnym ograniczeniu ich masy, stosowane są stopy ze zwiększoną zawartością Mg (0,1 do 0,3\% wag.), co jednak powoduje problemy z ich lutownością. Rozwiązaniem wspomnianego problemu może być zastosowanie topnika NOCOLOK $^{\circledR}$ z dodatkiem cezu lub zastosowanie materiału 5-warstwowego, w którym zastosowano warstwę separacyjną.

- Bardzo krytycznym parametrem stawianym obecnym wymiennikom ciepła, które mają kontakt z cieczą chłodzącą, jest pozostałość topnika z procesu lutowania znajdująca się wewnątrz wymiennika.

- W obszarze materiałów używanych do produkcji wymienników ciepła, nastąpił wyraźny postęp oferujący szereg nowoczesnych materiałów nie wymagających użycia topnika do procesu lutowania lub wykazujących zwiększoną odporność na korozję.

\section{Literatura}

[1] Ambroziak A., Lange A., Derlukiewicz W., Mosińska S.: Lutowanie twarde aluminium i jego stopów, Przegląd Spawalnictwa, 2/2009, s. 10-14.

[2] Frąckowiak E., Mroziński W.: Zastosowanie lutowania płomieniowego w produkcji aluminiowych samochodowych wymienników ciepła, Przegląd Spawalnictwa, 9/2007, s. 57-62.

[3] Materiały firmy Solvay Flux GmbH: The NOCOLOK ${ }^{\circledR}$ Flux Brazing Process, http://www.solvay.com/en/binaries/NOCOLOK_Brazing_Process-ende-179520.pdf

[4] Mirski Z., Granat K., Misiek A.: Lutowanie twarde aluminiowych wymienników ciepła w przemyśle motoryzacyjnym, Spajanie materiałów konstrukcyjnych , 2/2015, s. 32-34.

[5] Swiderski H.W., Lauzon D: Myths about Aluminium Brazing with Non-Corrosive Fluxes NOCOLOK® Flux Brazing Technology, Materiały firmy SoIvay Flux GmbH, http://www.aluminium-brazing.com/sponsor/nocolok/ Files/PDFs/31390.pdf
[6] Melander M., Oskarsson A., Haller S.: Next generation multilayer - MULTICLAD: Material for brazed heat exchanger applications, 8th International Congress Aluminum Brazing, 2014, s. 45-49.

[7] Hawksworth D.K., Westergard R., Nillson P.: Brazing properties of Trillium composite, 8th International Congress Aluminum Brazing, 2014, s. 84-88.

[8] Eckhard K., Janssen H. : CleanBraze: fluxless brazing of aluminum heat exchangers, 8th International Congress Aluminum Brazing, 2014, s. 50-51.

[9] Orman L., Swiderski H.W., Lauzon D. : Brazing of Aluminium Alloys with Higher Magnesium Content using Non-Corrosive Fluxes, Aluminum Brazing - News, Knowledge and Technology, http://www.aluminium-brazing. com, 3-7/2014.

[10] Garcia J., Massoulier C., Faille P. : Brazeability of Aluminum Alloys Containing Magnesium by CAB Process Using Cesium Flux, SAE Technical Paper 2001-01-1763, 2001, http://www.aluminium-brazing.com/sponsor/ nocolok/Files/PDFs/VTMS5_Garcia_NOCOLOK_Cs_Flux.pdf 